\title{
COMMENTS ON THE PAPER OF PROFESSOR ARAKAWA ON THE GROW'TH OF ICE CRYSTALS IN WATER
}

\author{
By J. W. GLeN \\ (Cavendish Laboratory, Cambridge)
}

THE beautiful photographs obtained by Professor Arakawa show clearly how ice crystals develop from the liquid, and in particular how the dendrites start. I would like to suggest another reason why the growth is initially in the form of a disc and only subsequently in the form of dendrites. There are two different factors that can determine the shape of growing crystals; one is the surface energy of the crystal, and the other is the ease with which heat can flow from the water to allow it to freeze onto the crystal. The first process tends to make crystals equiaxed and dominates when the rate of growth is small, the second promotes dendritic growth and occurs when the rate of growth is large. It seems from the photographs of Arakawa that, in the initial stages of growth, a disc-shaped crystal forms because, while the crystal properties of ice dictate a planar form, they do not dictate any preferred directions in this plane. At this stage no difficulty is experienced in getting rid of the latent heat. In fact the disc may be thought of as rather similar to the tip of the dendrite subsequently, formed. When the disc has grown to such a stage that its radius of curvature is large compared to a length determined by the rate of growth and the thermal conductivity of the melt, the heat flow term begins to dominate, and any small irregularities in the circular form of the disc tend to be enlarged as dendrites, despite the increased surface energy involved, because they stick out and can therefore dispose of the latent heat more easily. This would account for the "notched crystal." Finally, the dendrites in the direction in which growth is easiest grow faster than their neighbours to give the stellar shape.

This explanation differs from Arakawa's in that it does not depend on any internal stresses to account for the branching out of dendrites. His explanation is probably true in the case of the crystals whose branches had different crystallographic orientations from the mother needles, but it would seem to be unnecessary where, as in the case of the stellar crystals, no orientation difference is present.

\section{THE INSTITUTE OF LOW TEMPERATURE SCIENCE HOKKAIDO UNIVERSITY, JAPAN}

THE Institute of Low Temperature Science of the Hokkaido University, Japan, was established in I94I for the purpose of making researches on those natural phenomena which are caused by the winter cold experienced in Japan. It has six cold chambers for experimental work. These can be cooled as low as $-57^{\circ} \mathrm{C}$., five of them having a floor area $4 \mathrm{~m} . \times 4 \mathrm{~m}$. The fifth, which is four times as large as the others, is equipped with a wind tunnel.

The Institute comprises six research sections. Four are physics sections and the other two are biological and medical. The total number of research workers is twenty-eight.

The members of the physics sections are occupied mainly with investigations on the physical properties of snow and ice. After having carried out general research for the last eight years on various properties of ice and snow such as the thermal, mechanical and electrical aspects, most of the staff is now studying the mechanical properties of deposited snow from a rheological point of view. Physical researches have also been conducted for the last several years on the sea ice field on the north-east coast of Hokkaido.

The eastern coast of Hokkaido is invaded by dense sea fog in spring and summer. Although this fog is not directly related to winter cold members of the Institute have been engaged for the last four summers in studying the problem of the influence of forests planted along the sea coast in preventing fog.

Members of the biological section have been engaged in studying how plant bodies freeze. They have taken a large number of freezing curves of food plants such as potato or turnip, and have found 
many variations in them according to circumstances. They have also observed plant cells under the microscope while they were being cooled to freezing, and have found many different types of freezing which could be correlated with the variations of the freezing curves. They are now studying resistance against frost of frost-resisting insects such as slugs, caterpillars and the European corn-borers found most commonly in Hokkaido.

Members of the medical section, in conjunction with those of the biological section, are studying the cold preservation of blood. They are intending to find a way by which blood can be kept unfrozen even below $0^{\circ} \mathrm{C}$. without incurring any harmful change. They are also engaged in studying the influence of cold on bacteria.

The results of the research work are published in the Journal, "Teion-Kagaku (Low Temperature Science)," written in Japanese with a résumé in English, and in separate papers under the general title of "Contributions from the Institute of Low Temperature Science." Both are edited by the Institute. Twelve volumes of the former and three numbers of the latter have already been issued. The results of the investigation on sea fog were published in a separate book entitled "Studies on Fogs."

I 9 August I 954

Zyungo YoshidA

(Director, Institute of Low Temperature Science, Hokkaido University)

\section{O B I T U A R Y}

\section{JOHN GILL MCCALL}

John McCall died suddenly on 5 November 1954 in Alaska. He was 31. He left Pennsylvania State University when his country entered the war and saw some of the hardest fighting as a parachutist with a U.S. airborne division. After the war he decided to go to Alaska and continue his university career. He was a first-class ski-er and mountaineer--he was one of the few who have climbed Mount McKinley - and grew so fond of the Alaskan countryside that he decided to make his home there. He graduated in engineering in $195^{\circ}$, and came to Cambridge to take a Ph.D. in glaciology. He chose as his subject "The flow characteristics of a cirque glacier and their effect on glacier structure and cirque erosion," where his application of engineering techniques was especially valuable. During his three years he made four trips to Vesl-Skautbreen, a cirque glacier in Jotunheimen in Norway, where he jointly led the Cambridge party which so successfully investigated this little glacier by tunnels and careful survey and related work. It was in no small measure due to his genial character, his natural leadership, his persistence and his skill particularly in the field, that this considerable task was accomplished.

On receiving his $\mathrm{Ph} . \mathrm{D}$. in $\mathrm{I} 953$ he returned to the University of Alaska as a member of the teaching staff, and the following academic year was made Acting Head of the Department of Geology. He introduced a course in glaciology, a new departure for his University. He was also very proud of the fact that he was called in to advise an Alaskan firm of civil engineers about possible glacier encroachment on a projected road, and was therefore possibly the first glaciologist to be paid a consultant's fee.

He continued to ski and climb. He was coach to the University ski team; and in the spring of I 954 he led a rescue party, with great skill and complete success, up to II,000 ft. on Mount McKinley to bring back an injured climber.

His was an extraordinarily attractive personality; all associated with him will feel his loss deeply. A career full of promise has been tragically cut short and the Society has lost one of its strongest supporters. His widow and four children deserve the deepest sympathy. 